\title{
Methodological approach to the assessment of ecological tourism as a direction of sustainable development of the tourism industry
}

\author{
Elena Antamoshkina ${ }^{1, *}$, Ivan Korabelnikov ${ }^{1}$, Tatyana Daeva ${ }^{1}$, Tatjana Nazarova ${ }^{1}$, and \\ Natalia Morozova ${ }^{2}$ \\ ${ }^{1}$ Volgograd State Agricultural University, Universitetskiy Avenue, 26, 400002 Volgograd, Russia \\ ${ }^{2}$ The branch «Vzlet» of the Moscow Aviation Institute National Research University, st. \\ Dobrolyubova, 28, 416501 Akhtubinsk, Astrakhan region, Russia
}

\begin{abstract}
The article recommends a methodological approach, that includes the analysis of natural and recreational, cultural, historical, and socio-economic factors to assess the potential of ecotourism development. The indicators and parameters of the assessment are established, qualitative and quantitative values are determined, they enable evaluation of the impact of each criterion on the assessment of the potential for ecotourism development in points. The authors identified organizational and economic factors of ecotourism development in the region: insufficient funding for natural parks improvement activities; lack of equipped ecological trails and routes; insufficient information and personnel support. On the basis of the proposed methodology, the potential for ecotourism development in natural parks of the Volgograd region was assessed. The article highlights risks of ecological tourism development in the Volgograd region: the lack of a unified system of state accounting and monitoring of the state of natural resources; low efficiency of control and supervisory activities; the spread of environmentally non-adaptive forms of nature management in the region; the low level of ecological culture of the population. The potential for ecotourism development determines opportunities for the implementation of main functions of specially protected natural areas: ecological, scientific and educational, socio-economic, which together forms a system of conditions for sustainable development of rural areas.
\end{abstract}

\section{Introduction}

Steady deterioration in the environment quality leads to an increase in interest in ecotourism and its development. This is due to the formation of territories that ensure the preservation of natural environment and the expediency of ecological culture education of a person. As a result, the combined impact of ecotourism contributes to the preservation of natural environment and cultural landscapes. Based on global trends in the tourism industry, the conceptual model of ecotourism allows combining ecology, tourism, and

\footnotetext{
*Corresponding author: antamoshkina@mail.ru
} 
culture into a complex system and considering the influence of natural and climatic, recreational, and anthropogenic factors [1,2].

The concept of the Federal Target Program "Development of domestic and inbound tourism in the Russian Federation (2019-2025)" sets target priorities for the development of the Russian tourism industry in terms of global trends and with a special emphasis on the growth of interest in cultural and educational, active, recreational and ecological tourism. Among the regions with the highest level of tourist potential for ecotourism development are the Siberian, Far Eastern, Volga, Ural, North-Western, North-Caucasian and Southern Federal Districts.

The concept of the Federal Target Program proposes to develop tourism including ecotourism, on the basis of a project approach and formation of attractive tourist enlarged investment projects, taking into account natural and climatic, geographical, socio-cultural characteristics of the territories of the regions of Russia. The framework of such development, in fact, will be the formation and promotion of regional tourist brands in the tourist market, which can comprehensively identify the specific features of each individual region.

Therefore, it is highly topical to research the state and capacity of natural parks in modern conditions, to justify priority areas for using the ecotourism potential, as well as to develop proposals for improving the conditions for ecotourism development.

Experts of the tourism industry note the special role of ecotourism in the integrated development of rural areas based on the possibility of systematic accounting of socioeconomic, cultural, and environmental factors [3]. Scientific and research ideas about ecotourism have determined the details of regulatory and legal documents, in which ecotourism is considered from the standpoint of the "North American" model.

\section{Materials and Methods}

In order to form effective strategies for ecotourism development, it is necessary to analyze the potential of Russian regions in terms of assessing natural and recreational, cultural, historical, and socio-economic factors. Environmental problems and risks have an impact on the state of recreational potential of the territories, the implementation of which is an important condition for optimizing the work of natural parks. Therefore, it is highly topical to research the state and capacity of natural parks in modern conditions, to justify priority areas for using the ecotourism potential, as well as to develop proposals for improving the conditions for ecotourism development.

The proposed methodology for assessing the potential of ecotourism development within the territory of natural parks is based on the systematization and generalization of approaches presented in the studies of a number of modern scientists focusing on the analysis of tourist and recreational potential of the regions - I. Ziganshin, R. Kovalev, M. Stishov, K. Makarova [4-7]. The methodology involves the analysis of potential for ecotourism development, based on the results of an expert assessment of three groups of factors: natural and recreational, cultural and historical, and socio-economic. For each criterion, an indicator is defined, and qualitative and quantitative values are established, they allow evaluating the impact of each criterion on the assessment of development potential in points (Table 1).

Table 1. Methodology for assessing the potential of ecotourism development.

\begin{tabular}{|c|c|c|c|}
\hline \multicolumn{4}{|c|}{ I. Assessment of natural and recreational factors } \\
\hline Criterion & Indicator & $\begin{array}{c}\text { Assessment } \\
\text { indicators }\end{array}$ & $\begin{array}{c}\text { Assess } \\
\text { ment }\end{array}$
\end{tabular}


Table 1. Continued

\begin{tabular}{|c|c|c|c|}
\hline \multirow{3}{*}{ 1. Landscape diversity } & \multirow{3}{*}{ Availability of diversity } & Minimum, low & 1 \\
\hline & & Average & 2 \\
\hline & & High, maximum & 3 \\
\hline \multirow{3}{*}{ 2. Comfort of climate } & \multirow{3}{*}{ Comfort index (in points) } & $1-10$ points & 1 \\
\hline & & $11-60$ points & 2 \\
\hline & & $61-100$ points & 3 \\
\hline \multirow{3}{*}{ 3. Absolute heights } & \multirow{3}{*}{$\begin{array}{l}\text { Absolute height } \\
\text { difference (h in } \mathrm{m})\end{array}$} & Poorly broken relief & 1 \\
\hline & & $\begin{array}{l}\text { Moderately broken } \\
\text { relief }\end{array}$ & 2 \\
\hline & & Highly broken relief & 3 \\
\hline \multirow{3}{*}{ 4. Hydrographic network } & \multirow{3}{*}{$\begin{array}{l}\text { Density of hydrographic } \\
\text { network }\left(\mathrm{km} / \mathrm{km}^{2}\right)\end{array}$} & Thin & 1 \\
\hline & & Average & 2 \\
\hline & & Thick & 3 \\
\hline \multirow{2}{*}{$\begin{array}{l}\text { 5. Biodiversity of flora and } \\
\text { fauna }\end{array}$} & \multirow{2}{*}{$\begin{array}{l}\text { Quantitative diversity of } \\
\text { animal and plant species }\end{array}$} & Small & 1 \\
\hline & & Large & 3 \\
\hline \multirow{2}{*}{ 6. Balneological resources } & \multirow{2}{*}{$\begin{array}{c}\text { Availability of mineral } \\
\text { water sources }\end{array}$} & No & 1 \\
\hline & & Yes & 3 \\
\hline \multirow{3}{*}{$\begin{array}{l}\text { 7. Risk of natural disasters } \\
\text { (earthquakes, landslides, } \\
\text { mudslides, floods) }\end{array}$} & \multirow{3}{*}{ Risk level } & Max. & 1 \\
\hline & & Average & 2 \\
\hline & & Minimum & 3 \\
\hline \multicolumn{4}{|c|}{ II. Assessment of cultural and historical factors } \\
\hline \multirow{3}{*}{$\begin{array}{l}\text { 1. Diversity of historical and } \\
\text { cultural heritage sites }\end{array}$} & \multirow{3}{*}{$\begin{array}{l}\text { Composition of objects of } \\
\text { historical and cultural } \\
\text { heritage }\end{array}$} & $\begin{array}{c}\text { None or single } \\
\text { objects }\end{array}$ & 1 \\
\hline & & $\begin{array}{c}\text { There are certain } \\
\text { types of monuments }\end{array}$ & 2 \\
\hline & & $\begin{array}{c}\text { There are various } \\
\text { historical and cultural } \\
\text { monuments }\end{array}$ & 3 \\
\hline \multirow{2}{*}{ 2. Objects of religious worship } & \multirow{2}{*}{ Availability of objects } & No & 1 \\
\hline & & Yes & 3 \\
\hline \multirow{2}{*}{$\begin{array}{l}\text { 3. Functional zone of cultural } \\
\text { heritage objects protection }\end{array}$} & \multirow{2}{*}{$\begin{array}{l}\text { Availability of a } \\
\text { functional zone }\end{array}$} & No & 1 \\
\hline & & Yes & 3 \\
\hline \multirow{3}{*}{$\begin{array}{l}\text { 4. Preservation of traditions, } \\
\text { customs, folklore by the } \\
\text { indigenous population }\end{array}$} & \multirow{3}{*}{$\begin{array}{l}\text { Presence of indigenous } \\
\text { population leading a } \\
\text { traditional way of life }\end{array}$} & No & 1 \\
\hline & & $\begin{array}{c}\text { Elements of } \\
\text { traditional way of life } \\
\text { are preserved (for } \\
\text { display) } \\
\end{array}$ & 2 \\
\hline & & $\begin{array}{l}\text { Traditional way of } \\
\text { life is preserved }\end{array}$ & 3 \\
\hline \multicolumn{4}{|c|}{ III. Assessment of socio-economic factors } \\
\hline \multirow{3}{*}{$\begin{array}{l}\text { 1. Alternative use of land } \\
\text { resources }\end{array}$} & \multirow{3}{*}{$\%$ of land resources } & More than $30 \%$ & 1 \\
\hline & & $10-30 \%$ & 2 \\
\hline & & Less than $10 \%$ & 3 \\
\hline \multirow{2}{*}{$\begin{array}{l}\text { 2. Permanent resident } \\
\text { population }\end{array}$} & Population size (people) & $\begin{array}{l}\text { More than } 2000 \\
\text { people. }\end{array}$ & 1 \\
\hline & & Up to 2000 people. & 3 \\
\hline & & Low & 1 \\
\hline 3. Transport accessibility & Accessibility for tourists & Average & 2 \\
\hline & & High & 3 \\
\hline $\begin{array}{l}\text { 4. Organizations responsible } \\
\text { for tourist and recreational }\end{array}$ & Availability of & No & 1 \\
\hline activities & & Yes & 3 \\
\hline
\end{tabular}


Table 1. Continued

\begin{tabular}{|c|c|c|c|}
\hline $\begin{array}{c}\text { 5.Tourist infrastructure } \\
\text { sophistication (visit centers, } \\
\text { accommodation facilities, } \\
\text { public catering, medical care, } \\
\text { parking, infrastructure and } \\
\text { facilities of nature trails) }\end{array}$ & $\begin{array}{c}\text { Diversity and quantitative } \\
\text { composition }\end{array}$ & Weak & 1 \\
\cline { 3 - 4 } & & Good & 2 \\
\cline { 3 - 4 } 6. Sports infrastructure & Availability of objects & No & 3 \\
\cline { 3 - 4 } & Presence of a border area & Yes & 3 \\
\hline l. Bocation & No & 1 \\
\hline \multirow{2}{*}{ 8. Anthropogenic impact } & Load level & Yes & 3 \\
\cline { 3 - 4 } & & Strong & 1 \\
\cline { 3 - 4 } & & Average & 2 \\
\hline
\end{tabular}

\section{Results and Discussion}

Based on the proposed methodology, we will assess the potential for ecotourism development in the natural parks of the Volgograd region. The Volgograd region is a unique region of Russia, since its north-western part is located in the forest-steppe zone, and its east is located in the zone of semi-deserts, which actually turn into desert landscapes. In this regard, the very location at the junction of natural zones determines the peculiar importance of territories for biodiversity conservation [8].

At present, there are seven natural parks in the Volgograd region - "Nizhnekhopersky", "Tsimlyanskiye Peski" (Tsimlyansk sands), "Shcherbakovsky", "Volga-Akhtuba floodplain", "Ust-Medveditsky", "Donskoy", "Eltonsky". As a result of the assessment, natural parks were assigned points for each indicator. Table 2 presents the summary of the assessment results in the context of natural and recreational, cultural, historical, and socioeconomic factors that form the potential for ecological tourism development in natural parks of the Volgograd region.

Table 2. Assessment of the potential for ecotourism development in natural parks of the Volgograd region.

\begin{tabular}{|c|c|c|c|c|c|c|c|}
\hline \multirow[b]{2}{*}{ Groups of assessment factors } & \multicolumn{7}{|c|}{ Natural Parks } \\
\hline & 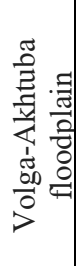 & 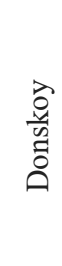 & 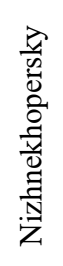 & 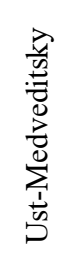 & 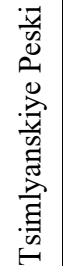 & 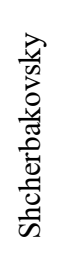 & $\begin{array}{l}\frac{\partial}{\tilde{V}} \\
\frac{\tilde{0}}{ \pm} \\
\frac{0}{1}\end{array}$ \\
\hline 1. Natural and recreational factors & 15 & 14 & 16 & 14 & 15 & 16 & 12 \\
\hline 1.1. Landscape diversity & 2 & 2 & 2 & 2 & 2 & 2 & 1 \\
\hline 1.2. Climate & 3 & 3 & 3 & 3 & 3 & 3 & 3 \\
\hline 1.3. Absolute heights & 1 & 1 & 3 & 1 & 1 & 3 & 1 \\
\hline 1.4. Hydrographic network & 3 & 2 & 2 & 2 & 3 & 2 & 2 \\
\hline 1.5. Biodiversity of flora and fauna & 3 & 3 & 3 & 3 & 3 & 3 & 1 \\
\hline 1.6. Balneological resources & 1 & 1 & 1 & 1 & 1 & 1 & 3 \\
\hline 1.7. Risk of natural disasters & 2 & 2 & 2 & 2 & 2 & 2 & 1 \\
\hline 2. Cultural and historical factors & 8 & 11 & 8 & 11 & 8 & 8 & 8 \\
\hline $\begin{array}{l}\text { 2.1. Diversity of historical and cultural } \\
\text { heritage sites }\end{array}$ & 2 & 3 & 2 & 3 & 2 & 2 & 2 \\
\hline
\end{tabular}


Table 2. Continued

\begin{tabular}{|c|c|c|c|c|c|c|c|}
\hline 2.2. Objects of religious worship & 3 & 3 & 3 & 3 & 3 & 3 & 3 \\
\hline $\begin{array}{l}\text { 2.3. Functional zones of cultural heritage } \\
\text { objects protection }\end{array}$ & 1 & 3 & 1 & 3 & 1 & 1 & 1 \\
\hline $\begin{array}{l}\text { 2.4. Preservation of traditions, customs, } \\
\text { folklore by the indigenous population }\end{array}$ & 2 & 2 & 2 & 2 & 2 & 2 & 2 \\
\hline 3. Socio-economic factors & 15 & 13 & 13 & 11 & 13 & 15 & 12 \\
\hline 3.1. 1. Alternative use of land resources & 1 & 1 & 1 & 1 & 2 & 1 & 1 \\
\hline $\begin{array}{l}\text { 3.2. Presence of permanent resident } \\
\text { population }\end{array}$ & 1 & 1 & 1 & 1 & 1 & 1 & 21 \\
\hline 3.3. Transport accessibility & 3 & 2 & 1 & 2 & 2 & 3 & 1 \\
\hline $\begin{array}{l}\text { 3.4. Organizations responsible for tourist } \\
\text { and recreational activities }\end{array}$ & 1 & 1 & 1 & 1 & 1 & 1 & 1 \\
\hline $\begin{array}{l}\text { 3.5. The level of development of tourist } \\
\text { infrastructure }\end{array}$ & 3 & 2 & 2 & 2 & 2 & 2 & 2 \\
\hline 3.6. Sports infrastructure & 3 & 3 & 3 & 1 & 1 & 3 & 1 \\
\hline 3.7. Border area location & 2 & 1 & 2 & 1 & 2 & 2 & 3 \\
\hline 3.8. Anthropogenic impact & 1 & 2 & 2 & 2 & 2 & 2 & 2 \\
\hline $\begin{array}{c}\text { Assessment of potential for ecotourism } \\
\text { development }\end{array}$ & 38 & 38 & 37 & 36 & 36 & 39 & 32 \\
\hline
\end{tabular}

It was found that in accordance with natural and recreational factors of development, the assessment distinguished the following natural parks: "Nizhnekhopersky", "Tsimlyanskiye Peski", "Shcherbakovsky", "Volga-Akhtuba floodplain". At the same time, when considering the total weight of cultural and historical potential of ecotourism development, the leading positions of the Ust-Medveditsky and Donskoy parks (about 30\% of the potential) should be noted, which is due to the allocation of historical and cultural functional zone and the desire of local population to preserve traditions, customs, and folklore of the Cossacks. From the point of view of socio-economic factors of the ecological tourism development, the natural parks "Volga-Akhtuba floodplain", "Shcherbakovsky", "Donskoy", "Tsimlyanskiye Peski", "Nizhnekhopersky" attract attention (about $40 \%$ of the potential). The infrastructure opportunities of ecotourism (including specially equipped parking lots, nature trails, sports infrastructure facilities) are used to a greater extent here.

As a result of the expert assessment of the potential for ecotourism development in the Volgograd region, according to the total number of points the leading positions are occupied by "Volga-Akhtuba floodplain", "Shcherbakovsky" and "Donskoy" (38-39 points). At the same time, there are low parameters of the recreational opportunities use of the natural park "Eltonsky", which is due to poor transport accessibility and ecological state of lake Elton - a highly saline lake - (a decrease in the quality of park's balneological resources, littering of the Elton healing mud and its unauthorized intake).

It is worthwhile to say that socio-economic component of the potential for ecotourism development is directly related to information support, the level of which, remains unreasonably low, both when considering regional system of specially protected natural territories, and in the context of studying natural parks functioning in the region [9]. Thus, only two natural parks - "Volga-Akhtuba floodplain" and "Nizhnekhopersky" - have their own websites, at the same time the websites are not adapted for foreign tourists, there are no English-language versions of their website pages. The information situation is slightly changed due to pages on social networks (VKontakte (InContact), Instagram), but the content of data provided is unable to contribute properly to the systematic development of ecotourism in natural parks. Furthermore, large national portals dedicated to Russian specially protected natural territories either give no coverage to the territories of regional 
subordination at all (information portal of the Ministry of Natural Resources), or the information provided is general, has a large amount of outdated data and is unable to provide an increase in ecotourism interest (the portal on domestic tourism - "Reserved Russia").

\section{Conclusions}

According to ecologists, general natural and ecological state of the Volgograd region is currently assessed as unsatisfactory. With that in mind, the main anthropogenic impacts on the territory of natural parks are largely associated with agricultural and recreational nature management, which form a whole range of consequences for natural and poorly modified geosystems of natural parks $[10,11]$. The character of environmental impact is determined by conditions and features of the geographical location and natural and ecological conditions of natural parks. The results of the analysis and assessment of impact factors on the geosystems of natural parks of the Volgograd region should be considered as the most important condition in the development and implementation of measures to ensure the environmental sustainability of regional systems.

Thus, the use of the potential of natural parks of the Volgograd region is determined within the integrity of implementation of main functions of specially protected natural areas: ecological one - determined by conservation of ecosystems; scientific and educational one, modern development of which is determined by new opportunities for digitalization; as well as economic and economic one, in which folk crafts and various unique types of agricultural activities have all the prerequisites to become important elements in the sustainable development of rural areas in the region.

\section{References}

1. T.P. Nazarova, A.S. Razin, News of the Nizhnevolzhsky agro-university complex: Science and higher professional education, 42 (2016)

2. V. Szekely, European Rural Development Network Studies, Rural Areas and Development, 7 (2010)

3. J. Sterman, Bysiness Dynamics. System Thinking and Modeling for a Complex World (2000)

4. I. Ziganshin, D. Ivanov, Russian Journal of Applied Ecology, 2 (2017)

5. R. Kovalev, Karelian scientific journal, 31 (2020)

6. K. Makarova, The territorial network of national parks of Russia as an object of ecological tourism: Dissertation of the candidate of geographical sciences (2015)

7. M. Stishov, Methodology for assessing the environmental efficiency of specially protected natural areas and their regional systems (2012)

8. L.O. Oganesyan, E.N. Fedyunina, Series: Advances in Economics, Business and Management Research, 47 (2019)

9. A. Rogachev, A. Shevchenko, V. Kuzmin, Works of SPIIRAN, 7 (2013)

10. A. Rogachev, E. Antamoshkina, IOP Conference Series: Earth and Environmental Science 403 (2019)

11. E. Antamoshkina, F. Rogachev Studies in Systems, Decision and Control 282 (2020) 